\title{
ANALISIS KEPUASAN PENGGUNA TERHADAP PENGGUNAAN E-LEARNING DENGAN METODE TAM DAN EUCS
}

\author{
Arny Lattu', Sihabuddin², Wisuda Jatmiko ${ }^{3}$ \\ Program Studi Sistem Informasi Universitas Nusa Putra \\ Jl Raya Cibatu Cisaat no 21 Cibolang Kaler, Sukabumi \\ e-mail: arny.lattu@nusaputra.ac.id, sihabuddin@nusaputra.ac.id, wisuda_jatmiko@nusaputra.ac.id \\ * Korespondensi: e-mail: arny.lattu@nusaputra.ac.id
}

\begin{abstract}
ABSTRAK
Pandemic Covid 19 yang terjadi saat ini memberikan dampak besar terhadap berbagai aktivitas dalam kehidupan manusia. Salah satunya pada sektor pendidikan dan kegiatan pemebalajaran di sekolah. Kebijakan dari pemerintah tentang WFH (work from home) menjadikan proses kegiatan pembelajaran di sekolah dihentikan sejak maret 2020 sampai waktu yang belum ditentukan. SMP Kristen 2 Salatiga sebagai salah satu institusi pendidikan dituntut untuk mengikuti perubahan ini yaitu pembelajaran jarak jauh dengan memanfaatkan platform pembelajaran e-learning. Penelitian ini dilakukan dengan metode TAM dan EUCS dengan beberapa faktor yang akan dibahas dari metode TAM yaitu faktor Persepsi Kegunaan( Perceived usefulness), Persepsi Kemudahan Penggunaan (Perceived Ease of Use), Sikap (Attitude) sedangkan dari metode EUCS yaitu Isi (Content), Akurasi( Accuracy), Tampilan( Format), Kemudahan( Ease), Ketepatan waktu( Timeliness). Kendala yang terjadi yaitu ketika pengguna tidak bisa memahami dengan benar cara penggunaan e-learning ini. Sehingga tentunya saja perlu dilakukan evaluasi faktor-faktor apa saja yang mempengaruhi terjadinya masalah tersebut. Subjek penelitian ini adalah siswa SMP kelas VII-IX SMP Kristen 2 Salatiga. Dengan menggunakan analisis SEM, maka hasil yang didapatkan terkait dengan kepuasan pengguna yaitu sebesar $96.7 \%$.
\end{abstract}

Kata Kunci: TAM, EUCS,e-learning, SEM

\section{ABSTRACT}

The current COVID-19 pandemic has had a significant impact on various activities in human life. One of them is in the education sector and learning activities in schools. The government's policy on WFH (work from home) has suspended the learning activities in schools from March 2020 until an undetermined time. As an educational institution, Christian Middle School 2 Salatiga is required to follow this change, namely distance learning, by utilizing the e-learning learning platform. This research was conducted using the TAM and EUCS methods with several factors that will be discussed from the TAM method, namely the Perceived usefulness factor, Perceived Ease of Use, Attitude, while from the EUCS method, namely Content, Accuracy( Accuracy), Display( Format), Ease( Ease), Timeliness( Timeliness). The obstacle occurs when the user cannot understand correctly how to use this e-learning. So, of course, it is necessary to evaluate what factors influence the occurrence of these problems. The subjects of this study were students of grade VII-IX SMP Kristen 2 Salatiga. Using SEM analysis, the results obtained are related to user satisfaction, $96.7 \%$.

Keywords: TAM, EUCS, e-learning, SEM

\section{Pendahuluan}

Pandemi COVID-19 yang terjadi di Indonesia membuat Pemerintah mencetus Peraturan Pemerintah tentang pembatasan sosial berskala besar yang tercantum dalam PP Nomor 21 Tahun 2020 yakni Pembatasan Sosial Berskala Besar Dalam Rangka Percepatan Penanganan Coronavirus Disease 2019 (COVID-19). Dengan adanya kebijakan social distancing maka hal ini berpengaruh pelaksanaan pendidikan terutama adanya pemberlakuan kegiatan belajar mengajar yang dilakukan di rumah dengan memanfaatkan teknologi informasi.

Pandemi COVID-19 menuntut sektor pendidikan seperti sekolah menengah pertama untuk melakukan berbagai perubahan maupun inovasi dan adaptasi demi kelancaran proses pelaksanaan kegiatan pembelajaran. Dengan demikian, tenaga pengajar yakni guru dan siswa harus siap beradaptasi dan menghadapi terobosan maupun tantangan baru terhadap perubahan sistem dalam pembelajaran yang diterapkan oleh pihak sekolah. Hal ini dapat dilihat dari pihak sekolah harus mengubah pembelajaran konvensional ke pembelajaran daring atau online. Salah satunya adalah dengan menggunakan media e-learning.

Sistem e-learning adalah bentuk paradigma baru dalam dunia pendidikan, sehingga harus dipersiapkan dengan 
baik karena rentan terhadap kegagalan [1] dan bersifat student centered [2]. Dalam rangka upaya mendukung proses pembelajaran secara online dan meningkatkan mutu pembelajaran ditengah pademic, SMP Kristen 2 Salatiga berupaya memberikan hasil yang terbaik terutama penggunaan teknologi baru. Proses pembelajaran daring dilakukan dengan memanfaatkan Learning Management System (LMS) Schoology. Service ini didesain untuk membantu guru membuat dan membagikan materi serta tugas secara paperless[3]. Selain itu juga dapat membantu kelancaran proses belajar dan mengajar yang dilakukan guru dan siswa. Perbandingan proses pembelajaran tatap muka dan pembelajaran daring dapat dilihat pada tabel berikut ini:

Tabel 1.

Perbandingan Pembelajaran

\begin{tabular}{|l|l|l|}
\hline No & Pembelajaran Tatap Muka & Pembelajaran Berbasis E-Learning \\
\hline 1 & Adanya pertemuan tatap muka & Tidak memerlukan tatap muka \\
\hline 2 & Waktunya sesuai jadwal & Waktunya fleksibel \\
\hline 3 & Membutuhkan ruangan kelas & Tidak membutuhkan ruang kelas \\
\hline 4 & Dominanya peran guru & Dominannya peran siswa \\
\hline 5 & Kemungkinan siswa pasif & Siswa aktif \\
\hline 6 & Adanya keterbatasan waktu & Tidak ada keterbatasan waktu \\
\hline 7 & Belajar siswa tergantung guru & Siswa belajar mandiri \\
\hline 8 & Materi ajar dari guru & Materi bias update sendiri \\
\hline 9 & Guru adalah subjek & Siswa adalah subjek \\
\hline
\end{tabular}

Sumber: [4] [2]

Pada prosesnya ditemukan beberapa kendala yang terjadi terutama bagi beberapa guru yang masih awam dengan penggunaan teknologi dalam mengoperasikan platform ini serta siswa kelas VII yang sebelumnya tidak pernah menggunakan media pembelajaran e-learning saat duduk di bangku sekolah dasar. Berbagai respon yang muncul dari pengguna menjadikan peneliti ingin memfokuskan penelitian ini pada aspek tingkat kepuasan dan tingkat penggunaan pengguna terhadap pembelajaran daring dengan menggunakan metode Technology Acceptance Model (TAM) dan metode End User Computing Satisfaction (EUCS). Melalui gabungan metode ini, dapat dipahami bahwa reaksi dan persepsi pengguna terhadap teknologi dapat mempengaruhi sikapnya dalam penerimaan penggunaan teknologi sehingga dapat mengetahui bagaimana tingkat kepuasan pengguna berdasarkan beberapa karakteristik antara lain hubungan antara staff IT dalam hal ini pengelola web based learning ( e-learning) dengan pemakai, kemudahan (ease of use) dan manfaat (usefulness) penggunaan sistem informasi yang disajikan dan cara kerja sistem penggunaan.

\section{TINJAUAN PUSTAKA}

\subsection{Penelitian Terdahulu}

Penelitian terdahulu yang dilakukan oleh Dien dan Dewi dengan judul Analisis Pengaruh Implementasi E-Learning Vilep di Poltekkes Kemenkes Palembang Dengan Pendekatan EUCS menunjukkan kepuasan pengguna e-learning Vilep secara simultan mencatat semua variable terpenuhi dan dilihat dari analisis dengan korelasi $\mathrm{R}^{2}$ sebesar 0.854 artinya variable satisfaction dapat dijelaskan oleh variable content, accuracy, format, ease of use dan timeliness sebesar $85.4 \%$ [5].

Penelitian lainnya dilakukan oleh Said dkk dimana penelitian ini berisi sebanyak 435 siswa berpartisipasi dalam pembelajaran dimana dari penelitian ini didapatkan adanya kemudahan dalam penggunaan elearning dan ditemukan terdapat pengaruh positif dari pemanfaatan media e-learning dari lima universitas berbeda di Uni Emirat Arab[6].

Kemudian penelitian lain yang dilakukan oleh Abdul Barir Hakim tentang efektifitas pemanfaatan beberapa media e-learning yang dilakukan di STMIK ESQ yaitu moodle, google classroom, dan edmodo. Dalam penelitian ini, peneliti mencoba membandingkan media e-learning manakah yang menarik minat mahasiswa dalam proses belajar mengajar sehingga hasil yang didapatkan adalah Moodle memiliki fiturfitur yang lebih lengkap dibanding edmodo dan google classroom akan tetapi memerlukan bantuan administrator dalam mempersiapkan penggunaannya [3]. 


\subsection{E-Learning}

Ada beberapa istilah yang digunakan dalam e-learning yakni: internet based learning ( belajar berbasis internet), virtual learning ( belajar melalui lingkungan maya) atau dengan kata lain belajar via daring. Pembelajaran daring dapat berupa technology base learning seperti audio atau web based learning dengan bantuan perangkat komputer dan internet. E-Learning merupakan segala aktivitas belajar yang menggunakan bantuan teknologi elektronik yang dapat diaplikasikan dalam pendidikan konvensional dan pendidikan jarak jauh [7]. Dalam hal ini bahan ajar atau materi pembelajaran dikemas dan akan dikirimkan ke dalam jaringan sehingga bisa diakses melalui internet. Selain itu pada e-learning,pengajar tidak sekedar mengunggah materi pembelajaran yang bisa diakses oleh peserta didik, tetapi pengajar juga melakukan evaluasi, menjalin komunikasi, berkolaborasi, dan mengelola aspek-aspek pembelajaran lainnya [8].

\subsection{Technology Acceptance Model (TAM)}

TAM merupakan salah satu jenis teori yang menerapkan pendekatan dengan fokus pada teori perilaku (behavioral theory) yang mana digunakan untuk mengkaji proses adopsi teknologi informasi. Berdasarkan istilahnya bahwa "A" pada kata TAM singkatan dari "Acceptance" artinya penerimaan. Sehingga bisa dikatakan bahwa TAM merupakan suatu model analisis untuk mengetahui perilaku pengguna akan penerimaan teknologi [9]. Secara lebih rinci, model ini memberikan penjelasan bagaimana penerimaan TI dengan dimensi-dimensi tertentu yang dapat mempengaruhi diterimanya TI oleh pengguna. Dengan dua variabel yaitu : kemudahan penggunaan (ease of use) dan kemanfaatan ( usefulness) atau dengan kata lain TAM terdiri dari dua konstruksi yaitu kemudahan pengguna ( perceived ease of use ) dan manfaat yang dipersepsikan (perceived useful). Berikut adalah model TAM yang akan digunakan dalam penelitian.

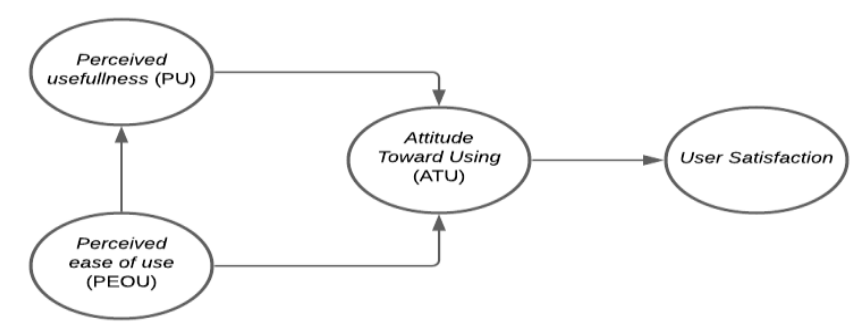

Gambar 1. Technology Acceptance Model (TAM)

\subsubsection{Persepsi Kemudahan}

Persepsi tentang kemudahan penggunaan sebuah teknologi didefinisikan sebagai suatu ukuran dimana seseorang percaya bahwa komputer dapat dengan mudah dipahami dan digunakan [10] [4]. Davis mengemukakan beberapa indikator kemudahan penggunaan TI antara lain meliputi:

1. Komputer sangat mudah dipelajari

2. Komputer mengerjakan dengan mudah apa yang diinginkan oleh pengguna

3. Komputer sangat mudah untuk meningkatkan keterampilan pengguna

4. Komputer sangat mudah untuk dioperasikan.

\subsubsection{Persepsi Kemanfaatan}

Persepsi terhadap kemanfaatan didefinisikan sebagai suatu ukuran dimana penggunaan suatu teknologi dipercaya akan memberi manfaat bagi orang yang menggunakannya [10][4] sehingga dapat dikatakan sebagai tingkatan dimana seseorang percaya bahwa penggunaan suatu subjek tertentu akan dapat meningkatkan prestasi kerja orang tersebut.

\subsection{End User Computing Satisfaction (EUCS)}

Model EUCS dikembangkan oleh Doll and Torkzadeh dimana digunakan untuk mengukur kepuasan pemakai terhadap sistem informasi. Dengan demikian, maka akan timbul penerimaan (acceptance) pada sistem informasi yang dipergunakan dalam suatu organisasi. Adapun lima komponen dalam instrumen 
EUCS yang dicetuskan oleh Doll and Torkzadeh yaitu; isi (content), akurasi (accuracy), bentuk (format), kemudahan (ease) dan ketepatan waktu (timeliness). Dibawah ini gambar instrumen EUCS

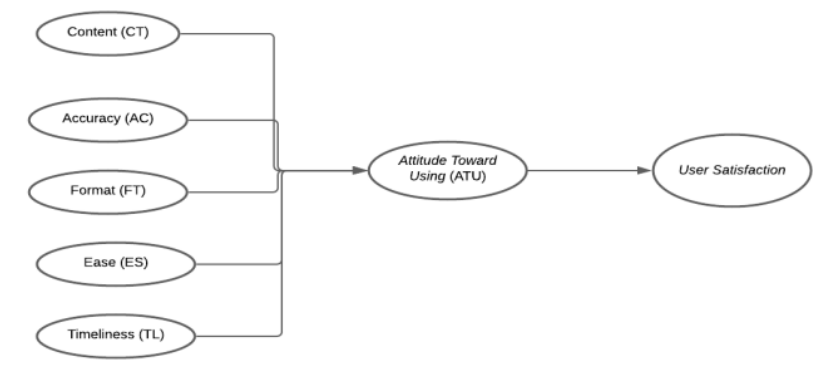

Gambar 2. End User Computing Satisfaction (EUCS)

\subsection{Model Integrasi TAM dan EUCS}

Dengan ada penelitian-penelitian yang dilakukan sebelumnya dengan menggabungkan metode TAM dan EUCS dimana dalam hal ini untuk menilai kepuasan pengguna sistem, konsep yang biasanya dapat digunakan adalah EUCS. Sedangkan dengan pengembangan TAM yang dilakukan oleh Said dan Malcolm [11] dengan beberapa indikator yang ditambahkan seperti compatibility, user characteristic, system rating, dan EUCS sebagai konstruk untuk mengukur penerimaan (acceptance). Melihat adanya hubungan antara konsep, penerimaan dan kepuasan atas teknologi informasi, maka dibangun sebuah model yang bisa mengakomodasi kedua hal tersebut yakni pengintergrasian antar variable dalam kedua model.

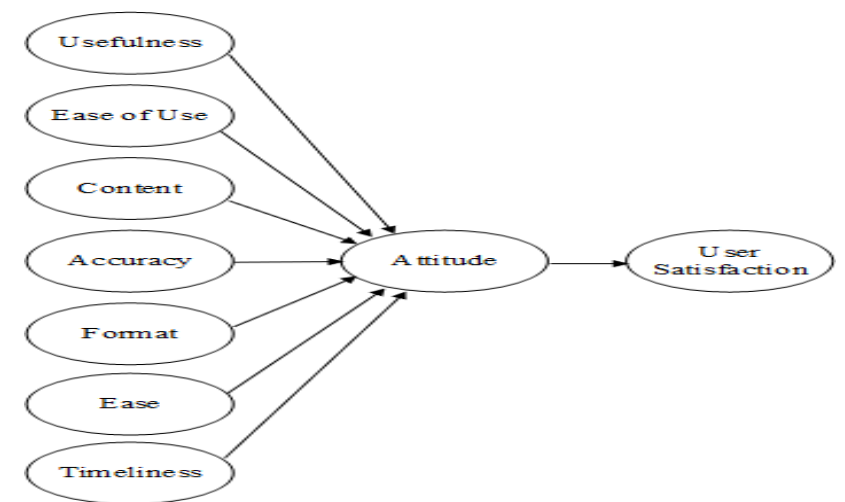

Gambar 3. Model Integrasi TAM dan EUCS

\section{METODE PENELITIAN}

\subsection{Jenis Penelitian}

Penelitian ini membagi variabel menjadi dua yaitu variabel independen (variabel bebas) dan variabel dependen ( variabel terikat). Variabel independen dalam penelitian ini yaitu kemanfaatan ( usefulness), kemudahan penggunaan (ease of use), isi (content), akurasi (accuracy), format(format), kemudahan pengguna (ease), ketepatan waktu( timeless) dan variabel dependennya yaitu variabel sikap (attitude) dan kepuasan pengguna (user satisfaction) Pada penelitian ini bentuk pengumpulan data yang dilakukan adalah dengan metode kuesioner tertutup yang diisi oleh para siswa pengguna sistem e-learning schoology yang disebarkan melalui google form secara online. Dengan berfokus pada Penetapan skala pengukuran jawaban pada kuesioner menggunakan skala likert yang biasa digunakan untuk mengukur sikap, pendapat, dan persepsi seseorang. Jenjang jawaban pada skala likert dapat dilihat pada tabel 2 dibawah ini. 
Tabel 2. Skala Likert

\begin{tabular}{|l|c|}
\hline \multicolumn{1}{|c|}{ Jawaban } & Bobot \\
\hline Sangat Tidak Setuju & 1 \\
\hline Tidak Setuju & 2 \\
\hline Kurang Setuju & 3 \\
\hline Setuju & 4 \\
\hline Sangat Setuju & 5 \\
\hline
\end{tabular}

Dengan pendekatan Structural Equation Modeling (SEM) akan dilakukan uji hipotesis dan software yang dipakai adalah SmartPLS 3.0 Hal ini dikarenakan alat analisis statistik ini mempunyai beberapa kelebihan karena pertama SEM-PLS sesuai dengan model penelitian ini yang menggunakan variabel yang tidak dapat diukur secara langsung dan telah memperhitungkan measurement error. Analisis SEM dapat mengaji secara simultan multiple dependence seperti model dalam penelitian ini. Adapun jumlah responden dalam penelitian ini sebanyak 255 responden yang terdiri dari seluruh siswa dari kelas kelas VII sampai dengan kelas IX SMP Kristen 2 Salatiga.

\subsection{Variabel Indikator Penelitian}

Pada penelitian ini, variabel dan indikator yang akan digunakan sebagai dasar penyebaran kuesioner dapat dilihat pada tabel 3 dibawah ini.

Tabel 3. Variabel dan Indikator [10] [11]

\begin{tabular}{|c|c|}
\hline Variabel & Indikator \\
\hline $\begin{array}{l}\text { PEU ( Perceives Ease of Use) / Kemudahan } \\
\text { Penggunaan) }\end{array}$ & $\begin{array}{ll}\text { 1. } & \text { PEU1 : Kemudahan dipelajari } \\
\text { 2. } & \text { PEU2 : Mudah dipahami/mengerti } \\
\text { 3. } & \text { PEU3 : Mudah sehingga mahir } \\
\text { 4. } & \text { PEU4 : Mudah digunakan }\end{array}$ \\
\hline PU ( Perceived Usefulness) / Kemanfaatan & $\begin{array}{l}\text { 1. U1: Lebih mudah } \\
\text { 2. U2: Meningkatkan efektifitas } \\
\text { 3. U3 : Lebih Cepat } \\
\text { 4. } \\
\text { U4: Meningkatkan produktifitas }\end{array}$ \\
\hline Content (Isi) & $\begin{array}{ll}\text { 1. } & \text { C1: informasi tepat } \\
\text { 2. } & \text { C2: isi informasi memenuhi } \\
\text { 3. } & \text { C3: informasi yang cukup } \\
\text { 4. } & \text { C4: adanya waktu dan tanggal untuk } \\
& \text { akses e-learning }\end{array}$ \\
\hline Accuracy ( Keakuratan) & $\begin{array}{l}\text { 1. A1: Informasi yang dihasilkan akurat } \\
\text { 2. A2: Puas dengan akurasi sistem } \\
\text { 3. A3: jarang error dengan akurasi } \\
\text { sistem }\end{array}$ \\
\hline Format ( Tampilan) & $\begin{array}{ll}\text { 1. } & \text { F1: ukuran huruf normal (jelas dan } \\
\text { terbaca) } \\
\text { 2. }\end{array}$ \\
\hline Ease (Kemudahan) & $\begin{array}{ll}\text { 1. } & \text { E1: User friendly } \\
\text { 2. } & \text { E2: Mudah dioperasikan } \\
\text { 3. } & \text { E3: Mudah dalam download } \\
\text { 4. } & \text { E4: Mudah dalam menerima } \\
& \text { pemberitahuan }\end{array}$ \\
\hline Timeliness( Ketepatan waktu) & $\begin{array}{l}\text { 1. T1: Sistem memberikan alert// } \\
\text { pemberitahan yang cepat saat terjadi } \\
\text { kesalahan penggunaan sistem } \\
\text { 2. T2: Cepat dalam mendwonload } \\
\text { dokumen }\end{array}$ \\
\hline Attitude Toward Using Technology & AT1 : Senang menggunakan teknologi \\
\hline
\end{tabular}




\begin{tabular}{|l|l|}
\hline & AT2: Memberikan kesenangan \\
& AT3: Antusias \\
\hline User Satifaction & 1. S1: Dapat diandalkan \\
& 2. S2: Aman digunakan \\
\hline
\end{tabular}

\subsection{Hipotesis Penelitian}

Hipotesis penelitian yang dibuat berdasarkan rumusan masalah kemudian dirancang sebagai dasar untuk pengolahan data menggunakan software smartPLS. Berdasarkan gambar 3, terdapat beberapa hipotesis yang dapat digunakan antara lain:

1. Hipotesis 1(H1): Adanya pengaruh positif dari Perceived usefulness terhadap sikap perilaku pada pengguna e-learning di SMP X

2. Hipotesis $2(\mathrm{H} 2)$ : Adanya pengaruh positif dari Perceived ease of use (PEU) terhadap sikap perilaku pada pengguna e-learning di SMP X

3. Hipotesis $3(\mathrm{H} 3)$ : Adanya pengaruh positif dari variabel content terhadap sikap perilaku pada pengguna e-learning di SMP X.

4. Hipotesis H4 (H4): Adanya pengaruh positif dari variabel accuracy terhadap sikap perilaku pada pengguna e-learning di SMP X

5. Hipotesis 5 (H5): Adanya pengaruh positif dari variabel format terhadap sikap perilaku pada pengguna e-learning di SMP X

6. Hipotesis $6(\mathrm{H} 6)$ : Adanya pengaruh positif dari variabel ease terhadap sikap perilaku pada pengguna e-learning di SMP X

7. Hipotesis 7 (H7): Adanya pengaruh positif dari variabel timeliness terhadap sikap perilaku pada pengguna e-learning di SMP X

8. Hipotesis 8(H8): Adanya pengaruh positif dari variabel attitude terhadap user satisfaction pada pengguna e-learning di SMP X

\section{HASIL DAN PEMBAHASAN}

Penelitian ini dilakukan untuk menganalisis sikap perilaku dan tingkat kepuasan siswa dalam menggunakan e-learning selama pandemic Covid 19. Proses kegiatan belajar mengajar yang terjadi di rumah membuat para siswa harus menggunakan laptop atau handphone dalam mengakses e-learning.

Pada penelitian ini, pengujian hipotesis akan dilakukan dengan analisis Partial Least Square (PLS) dengan software pendukungnya yaitu SmartPLS 3.0 dimana diagram model yang akan digunakan dapat dilihat pada gambar 4 .

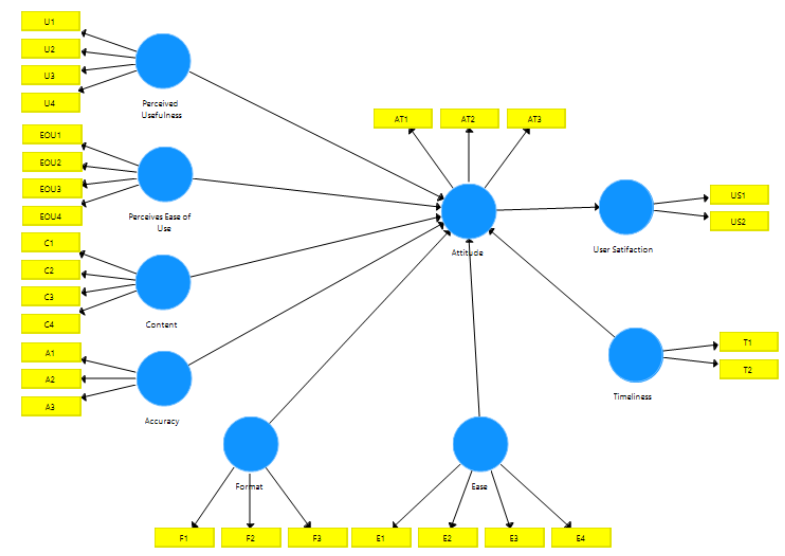

Gambar 4. Diagram Jalur Pemodelan 
Dalam menilai pendekatan yang dilakukan valid dan reliabel atau tidak maka dilakukan model pengukuran atau biasa disebut outer model. Hal ini digunakan untuk mengukur uji validitas item yang terdiri dua bagian yaitu validitas konvergen dan validitas diskriminan, composite reliability, uji inner $\mathrm{R}$

1. Uji Validitas Konvergen

Dalam uji validitas konvergen dapat dilihat pada skor outer loading. Uji validitas konvergen digunakan untuk membuktikan bahwa pertanyaan-pertanyaan pada setiap variabel dapat dipahami oleh responden. Dengan melihat skor pada fungsi outer loading yang besarnya 0.7 ke atas pertanyaan-pernyataan bagus dan memadai. Menurut Hair dkk dalam Johandri, suatu pernyataan dikatakan valid jika memiliki nilai $\mathrm{p}$ signifikan sebesar 0.5 [2]. Karena uji validitas konvergennya dilakukan dengan software SmartPls maka skor validnya yaitu 0.7 per item pertanyaan artinya sebesar $70 \%$ kuesioner valid. Berdasarkan kuesioner yang sudah dikumpulkan, maka dapat dilihat hasil uji validitas konvergennya pada gambar 5

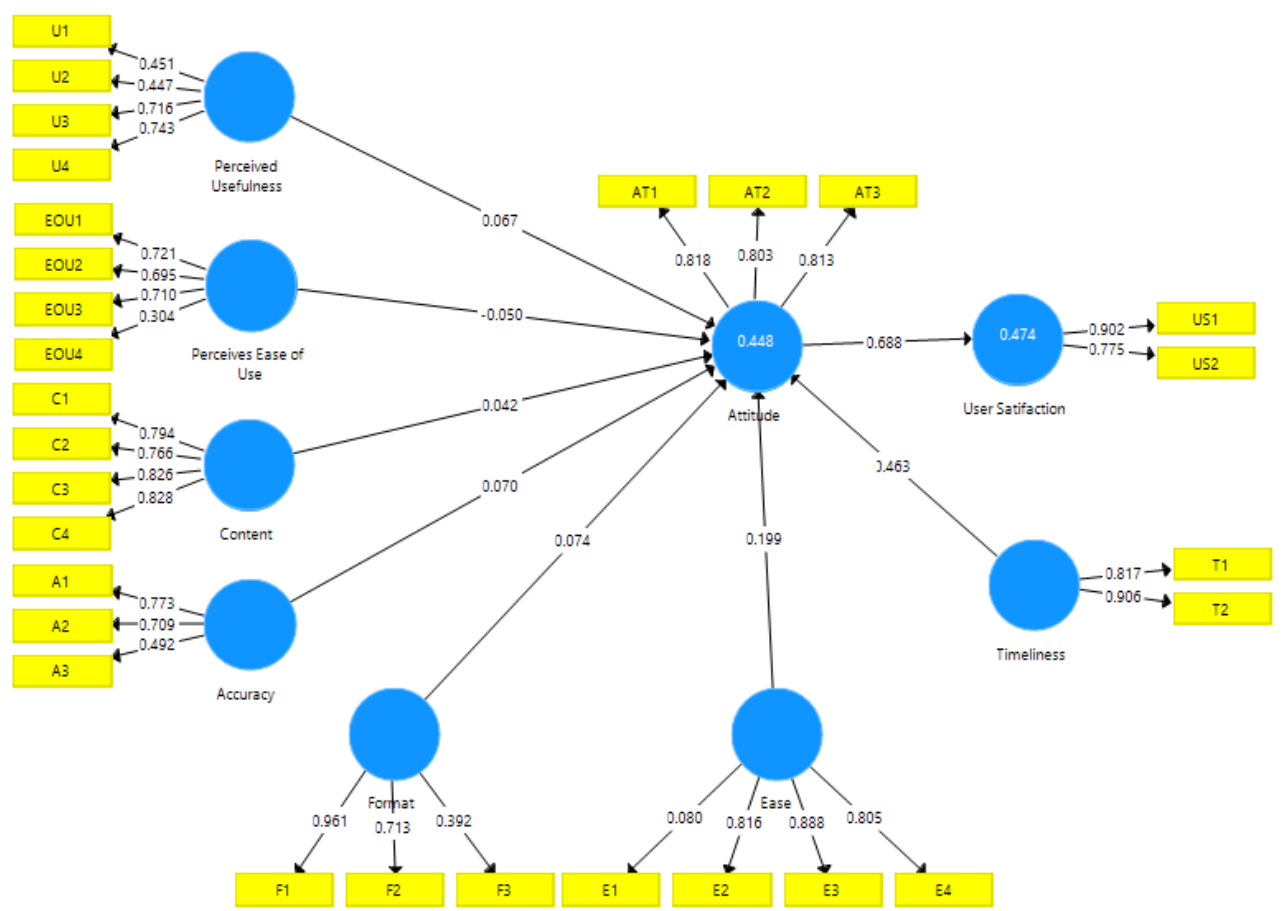

Gambar 5. Uji Validitas Konvergen

Berdasarkan hasil uji validitas konvergen, terdapat beberapa indikator pernyataan pada kuesioner yang skornya $<0.7$ yang dapat dilihat pada tabel 4 dibawah ini.

Tabel 3. Hasil Uji Validitas Konvergen

\begin{tabular}{|l|l|}
\hline \multicolumn{1}{|c|}{ Variabel } & \multicolumn{1}{c|}{ Indikator Valid dan Tidak Valid } \\
\hline $\begin{array}{l}\text { PEU ( Perceives Ease of Use) / Kemudahan } \\
\text { Penggunaan) }\end{array}$ & $\begin{array}{l}\text { Valid :iIndikator nomor 1 dan 3 } \\
\text { Tidak Valid : indikator nomor 2 dan } 4\end{array}$ \\
\hline PU ( Perceived Usefulness) / Kemanfaatan & $\begin{array}{l}\text { Valid : indikator nomor 3 dan 4 } \\
\text { Tidak Valid : indikator nomor 1 dan } 2\end{array}$ \\
\hline Content (Isi) & Valid \\
\hline Accuracy ( Keakuratan) & $\begin{array}{l}\text { Valid : Indikator 1 dan 2 } \\
\text { Tidak Valid : indikator 3 }\end{array}$ \\
\hline Format ( Tampilan) & $\begin{array}{l}\text { Valid : indikator nomor 1 dan 2 } \\
\text { Tidak Valid : indikator nomor 3 }\end{array}$ \\
\hline Ease (Kemudahan) & $\begin{array}{l}\text { Valid : indikator nomor 2,3, dan } 4 \\
\text { Tidak Valid : indikator nomor 1 }\end{array}$ \\
\hline Timeliness( Ketepatan waktu) & Valid \\
\hline Attitude Toward Using Technology & Valid \\
\hline User Satifaction & Valid \\
\hline
\end{tabular}


Karena adanya beberapa indikator yang tidak valid, maka indikator tersebut harus dihapus dan di lakukan pengujian kembali sehingga hasil uji validitas konvergen dapat dilihat pada gambar 6 dibawah ini.

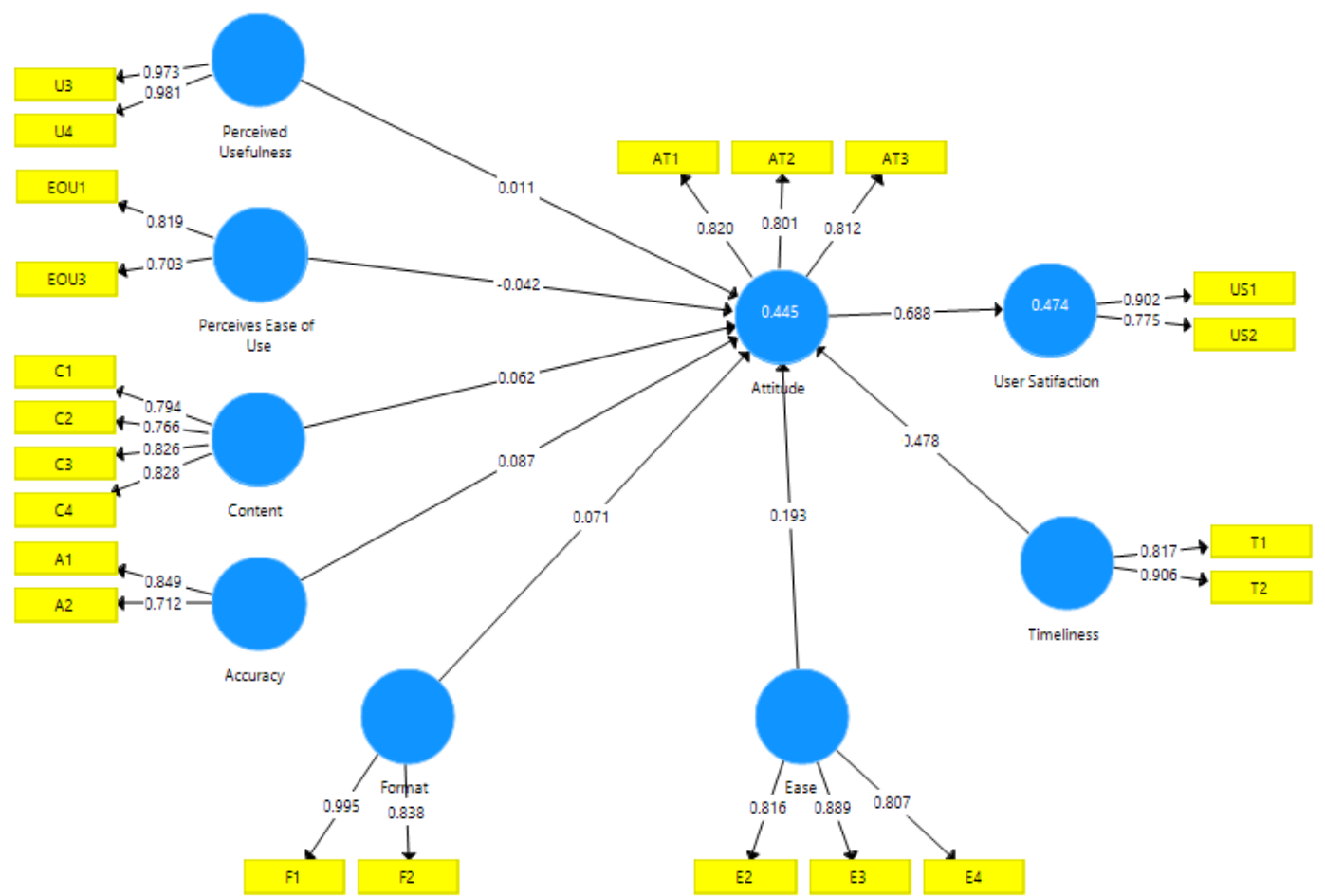

Gambar 6. Hasil Uji Validitas Konvergen dengan Outer Loading < 0.7

\section{Uji Nilai Ave Variance Extracted (AVE)}

Setelah melakukan uji nilai validitas konvergen, tahapan selanjutnya adalah melihat nilai Average Variance Extracted (AVE) pada konstrak laten. Hal ini karena semakin besarnya representasi variabel manifest terhadap konstruk latennya maka varian atau keberagaman variabel akan semakin besar [12]. Nilai AVE yang baik dengan menunjukkan ukuran convergent validity minimal 0.5 .

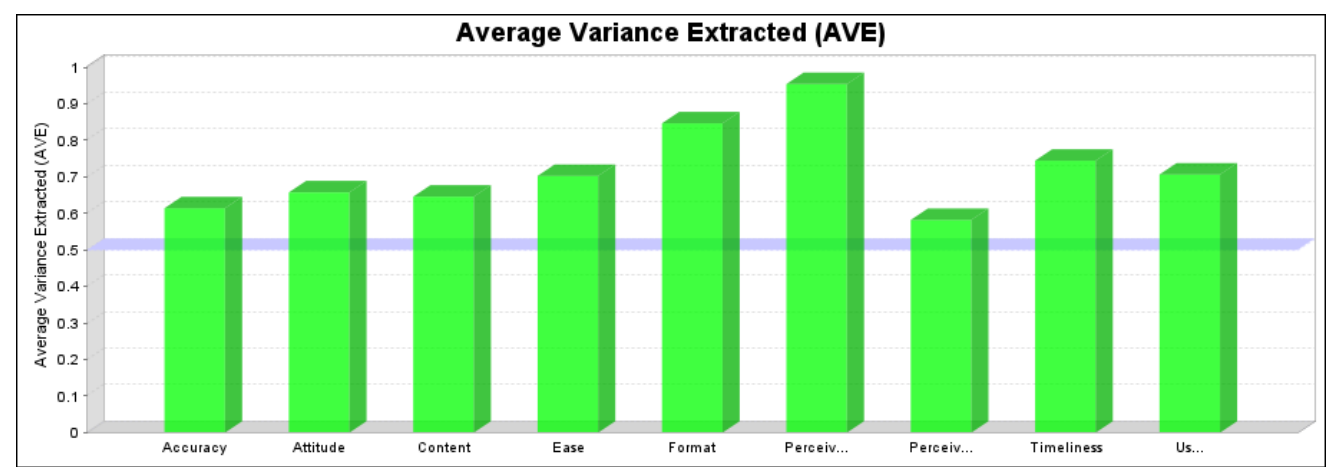

Gambar 7. Hasil AVE

Berdasarkan hasil yang telah diuji, AVE semua konstruk atau indikator memiliki nilai diatas 0.5 maka nilai AVE pada penelitian ini memiliki ukuran convergent validity.

\section{Uji Validitas Diskriminan}

Selain melakukan uji validitas konvergen, akan dilakukan juga pengujian validitas diskriminan dengan membandingan nilai yang diperoleh pada tabel cross loading Indikator yang sudah diuji dinyatakan valid jika nilai loading tertinggi pada konstruk yang dituju dibandingkan dengan besaran nilai konstruk loading lain yang dapat dilihat pada gambar 7 dibawah ini. 
JURSISTEKNI (Jurnal Sistem Informasi dan Teknologi Informasi) Vol 4, No.1, January 2022: Hal 39 - 50 ISSN. P: 2715-1875, E: 2715-1883

\begin{tabular}{|c|c|c|c|c|c|c|c|c|c|}
\hline & Accuracy & Attitude & Content & Ease & Format & $\begin{array}{c}\text { Perceived } \\
\text { Usefulness }\end{array}$ & \begin{tabular}{c|} 
Perceives \\
Ease of Use
\end{tabular} & Timeliness & User Satifaction \\
\hline $\mathrm{Al}$ & 0,849 & 0,226 & 0,274 & 0,255 & 0,104 & 0,040 & 0,272 & 0,237 & 0,135 \\
\hline$A 2$ & 0,712 & 0,170 & 0,112 & 0,104 & $-0,022$ & 0,056 & 0,101 & 0,114 & 0,138 \\
\hline ATl & 0,237 & 0,820 & 0,206 & 0,529 & 0,028 & 0,106 & 0,120 & 0,634 & 0,542 \\
\hline AT2 & 0,232 & 0,801 & 0,230 & 0,363 & 0,060 & 0,116 & 0,189 & 0,456 & 0,514 \\
\hline AT3 & 0,152 & 0,812 & 0,236 & 0,392 & 0,095 & 0,119 & 0,190 & 0,445 & 0,618 \\
\hline $\mathrm{Cl}$ & 0,161 & 0,199 & 0,794 & 0,258 & $-0,003$ & $-0,121$ & 0,798 & 0,266 & 0,141 \\
\hline $\mathrm{C} 2$ & 0,167 & 0,196 & 0,766 & 0,247 & $-0,033$ & $-0,180$ & 0,716 & 0,275 & 0,141 \\
\hline $\mathrm{C} 3$ & 0,244 & 0,253 & 0,826 & 0,299 & 0,061 & 0,081 & 0,370 & 0.277 & 0,180 \\
\hline $\mathrm{C} 4$ & 0,246 & 0,228 & 0,828 & 0,240 & 0,142 & 0,036 & 0,371 & 0,217 & 0,144 \\
\hline E2 & 0,200 & 0,404 & 0,187 & 0,816 & $-0,136$ & 0,177 & 0,193 & 0,500 & 0,293 \\
\hline E3 & 0,285 & 0,502 & 0,263 & 0,889 & $-0,021$ & 0,120 & 0,209 & 0,592 & 0,389 \\
\hline E4 & 0,107 & 0,429 & 0,370 & 0,807 & $-0,051$ & 0,093 & 0,357 & 0,567 & 0,327 \\
\hline PEU1 & 0,160 & 0,170 & 0,751 & 0,252 & $-0,041$ & $-0,154$ & 0,819 & 0,252 & 0,115 \\
\hline PEOU3 & 0,234 & 0,137 & 0,232 & 0,201 & $-0,013$ & 0,146 & 0,703 & 0,141 & 0,108 \\
\hline $\mathrm{Fl}$ & 0,063 & 0,082 & 0,073 & $-0,076$ & 0,995 & 0,062 & $-0,031$ & 0,017 & 0,035 \\
\hline $\mathrm{F} 2$ & 0,051 & 0,014 & $-0,038$ & $-0,075$ & 0,838 & 0,064 & \begin{tabular}{|c|}
$-0,067$ \\
\end{tabular} & $-0,008$ & 0,047 \\
\hline $\mathrm{Tl}$ & 0,149 & 0,458 & 0,228 & 0,556 & $-0,050$ & 0,146 & 0,255 & 0,817 & 0,249 \\
\hline $\mathrm{T} 2$ & 0,241 & 0,624 & 0,316 & 0,588 & 0,057 & 0,178 & 0,211 & 0,906 & 0,436 \\
\hline $\mathrm{U} 3$ & 0,032 & 0,124 & $-0,051$ & 0,155 & 0,066 & 0,973 & $-0,027$ & 0,182 & 0,102 \\
\hline $\mathrm{U} 4$ & 0,080 & 0,147 & $-0,035$ & 0,144 & 0,059 & 0,981 & $-0,024$ & 0,188 & 0,123 \\
\hline US1 & 0,179 & 0,672 & 0,202 & 0,427 & 0,026 & 0,148 & 0,150 & 0,433 & 0,902 \\
\hline US2 & 0,100 & 0,459 & 0,102 & 0,221 & 0,041 & 0,027 & 0,086 & 0,227 & 0,775 \\
\hline
\end{tabular}

Gambar 7. Hasil Uji Validitas Diskriminan

Berdasarkan hasil uji validitas diskriminan pada gambar 7 diatas menyatakan bahwa valid karena dibandingkan dengan korelasi indikator lainnya memiliki nilai paling tinggi.

4. Uji Reliabilitas Konstruk

Setelah menguji dan melihat hasil dari validitas diskriminan indikator dinyatakan valid selanjutnya menentukan hasil uji reliabilitas konstruk menggunakan perhitungan SmartPls dimana indikator dinyatakan reliabel apabila Cronbach Alpha dan composit reliability semua variabel laten dengan nilai diatas 0.7. berikut hasil uji reliabilitas dengan software SmartPls.

Tabel 4. Hasil Uji Reliabilitas Konstruk

\begin{tabular}{|l|c|c|}
\hline & Cronbach's Alpha & $\begin{array}{l}\text { Composite } \\
\text { Reliability }\end{array}$ \\
\hline Accuracy & 0,740 & 0,760 \\
\hline Attitude & 0,741 & 0,852 \\
\hline Content & 0,819 & 0,879 \\
\hline Ease & 0,788 & 0,876 \\
\hline Format & 0,878 & 0,916 \\
\hline $\begin{array}{l}\text { Perceived } \\
\text { Usefulness }\end{array}$ & 0,952 & 0,977 \\
\hline $\begin{array}{l}\text { Perceives } \\
\text { Ease of } \\
\text { Use }\end{array}$ & 0,727 & 0,735 \\
\hline Timeliness & 0,774 & 0,853 \\
\hline $\begin{array}{l}\text { User } \\
\text { Satifaction }\end{array}$ & 0,797 & 0,827 \\
\hline
\end{tabular}

5. Uji Inner Model

Tahapan selanjutnya melakukan pengujian $\mathrm{R}^{2}$ dimana nilai $\mathrm{R}^{2}$ mempunyai 3 kategori diantaranya 0.67 itu substansial, 0.33 adalah moderat, dan 0.19 itu lemah. Berikut adalah hasil ji perhitungan $\mathrm{R}^{2}$ menggunakan software SmartPls. 


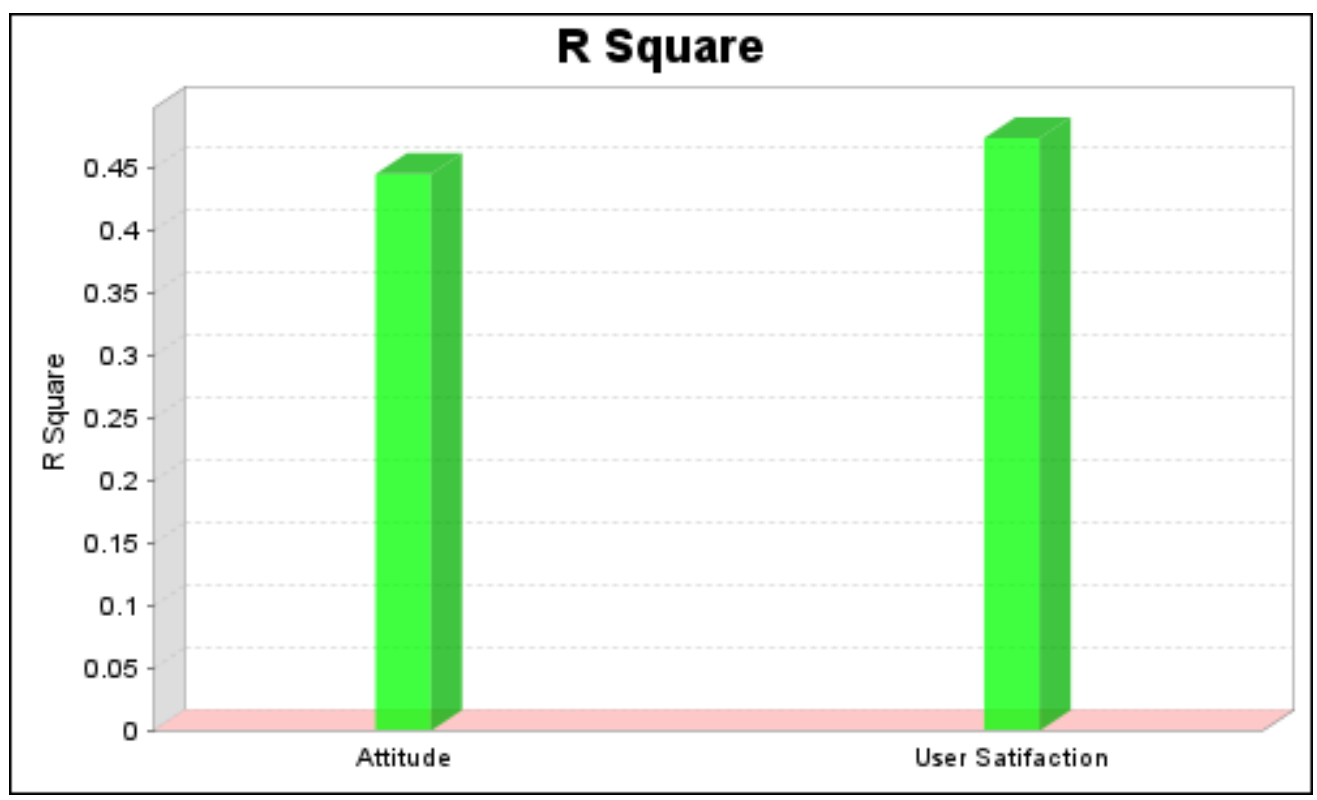

Gambar 8. Hasil Uji Perhitungan R

Berdasarkan data gambar 8 diperoleh nilai $\mathrm{R}^{2}$ variabel Attitude sebesar 0.45 yang termasuk klasifikasi moderat dan nilai R2 pada variabel User Satisfaction sebesar 0.48 yang juga termasuk klaisifikasi moderat.

\section{Uji Hipotesis}

Langkah terakhir pada penelitian ini yaitu dengan melakukan uji hipotesis dimana tingkat signifikan sebesar $5 \%$ atau 0.05 . pada pengujian hipotesis penelitian ini akan mencari nilai koefisien yaitu dengan membandingkan $\mathrm{t}$ hitung dan $\mathrm{t}$ tabel. Apabila $\mathrm{t}$ hitung $>\mathrm{t}$ tabel maka nilai koefisien dapat dikatakan signifikan. Pada penelitian ini, nilai t tabel sebesar 1.65.

Tabel 5. Output Path Coefficient

\begin{tabular}{|l|c|c|c|}
\hline & $\begin{array}{c}\text { Sampel Asli } \\
(\mathrm{O})\end{array}$ & T Statistik & Status \\
\hline Accuracy -> Attitude & 0.087 & 1.841 & Diterima \\
\hline $\begin{array}{l}\text { Attitude -> User } \\
\text { Satifaction }\end{array}$ & 0,688 & 9.672 & Diterima \\
\hline Content -> Attitude & 0.062 & 1.821 & Diterima \\
\hline Ease -> Attitude & 0.193 & 2.970 & Diterima \\
\hline Format -> Attitude & 0.071 & 1.052 & Ditolak \\
\hline $\begin{array}{l}\text { Perceived Usefulness - } \\
>\text { Attitude }\end{array}$ & 0.180 & 2.237 & Dterima \\
\hline $\begin{array}{l}\text { Perceived Ease of Use - } \\
>\text { Attitude }\end{array}$ & -0.042 & 0,735 & Ditolak \\
\hline Timeliness ->Attitude & 0.478 & 1,853 & Diterima \\
\hline
\end{tabular}

Sesuai dengan hasil output path coefficient pada tabel 5 dalam mengukur penerimaan teknologi elearning dan tingkat kepuasan pengguna dalam hal ini para siswa di SMP Kristen 2 Salatiga, maka dapat dikatakan hasil hipotesisnya sebagai berikut:

1. H1: Adanya pengaruh positif dari Perceived usefulness terhadap sikap perilaku Attitude pada pengguna e-learning di SMP X. Berdasarkan tabel 5, hasil uji hipotesis menunjukkan Hipotesis 1 diterima dengan nilai $\mathrm{T}$ statistik terhadap Attitude sebesar 2.237. Karena nilai t hitung lebih besar dari t tabel yaitu 1.841 lebih besar dari 1.65.

2. $\mathrm{H} 2$ : Berdasarkan tabel $5, \mathrm{H} 2$ ditolak karena nilai t hitung lebih kecil dari t tabel dimana nilai 0.735 lebih kecil dari 1.65. Variabel perceived ease of use tidak memiliki pengaruh positif terhadap attitude. 
3. H3: Adanya pengaruh positif dari variabel content terhadap sikap perilaku pada pengguna e-learning di SMP X. Nilai t hitung lebih besar dari t tabel yaitu 1.841 lebih besar dari 1.65 sehingga H3 diterima.

4. H4: Adanya pengaruh positif dari variabel accuracy terhadap sikap perilaku pada pengguna elearning di SMP X dengan nilai t hitung lebih besar dari nilai t tabel yaitu sebesar 1.841.

5. H5: H5 ditolak karena nilai t hitung lebih kecil dari t tabel yaitu sebesar 1.052.

6. H6: Adanya pengaruh positif dari variabel ease terhadap sikap perilaku pada pengguna e-learning di SMP X dengan nilai thitung 2.970 lebih besar dari nilai t tabel 1.65 sehingga H6 diterima.

7. H7: Adanya pengaruh positif dari variabel timeliness terhadap sikap perilaku pada pengguna elearning di SMP X sehingga H7 diterima dengan nilai t hitung 1.853 lebih besar dari nilai t tabel.

8. H8: Adanya pengaruh positif dari variabel attitude terhadap user satisfaction pada pengguna elearning di SMP X dengan nilai t hitung lebih besar dari nilai t tabel yaitu 9.672 yang artinya H8 diterima.

\section{KESIMPULAN}

Penelitian ini memiliki tujuh hipotesis yang diajukan, diantaranya enam hipotesis diterima yaitu $\mathrm{H} 1$, H3, H4, H6, H7, H8 dan dua hipotesis ditolak yaitu H2 dan H3. Dari metode TAM, variabel perceived usefulness memiliki pengaruh positif pada sikap attitude pengguna dalam kesuksesan penerapan e-learning sedangkan dari metode EUCS, variabel ease memiliki pengaruh terbesar pada sikap pengguna e-learning. Selanjutnya melihat dari variabel sikap maka didapatkan kepuasan pengguna e-learning sebesar 9.672 atau $96.7 \%$.

Penelitian ini memiliki keterbatasan karena tidak membahas dari segi eksternal seperti gender, experience sehingga pada penelitian berikutnya dapat membahas dari faktor-faktor eksternal yang ditemukan.

\section{DAFTAR PUSTAKa}

[1] I. M. S. I. K. Suwintana, “Competencies To Actual Usage of E-Learning : a Path Diagram Model,” J. Sist. Inf., vol. II, pp. 59-67, 2015.

[2] J. Iqbal and A. -, "Metode Pembelajaran E-Learning Menggunakan Technology Acceptance Modelling (TAM) Untuk Pembelajaran Akuntansi," InFestasi, vol. 14, no. 2, p. 116, 2019, doi: 10.21107/infestasi.v14i2.4856.

[3] A. Barir Hakim, "Efektivitas Penggunaan ELearning Moodle,Google Classroom Dan Edmodo.,” J. IStatement, vol. Vol.02, p. 2, 2016.

[4] E. Yulianto, "Pengaruh Persepsi Kemudahan Dan Persepsi Kemanfaatan Terhadap Pemanfaatan E-Learning Dengan Model TAM di," J. Bisnis Teor. dan Implementasi, vol. 53, no. 1, pp. 59-65, 2013, [Online]. Available: http://dx.doi.org/10.1016/j.encep.2012.03.001.

[5] D. Novita, "Analisis Pengaruh Implementasi E-Learning Vilep di Poltekkes Kemenkes Palembang dengan Pendekatan EUCS," JATISI (Jurnal Tek. Inform. dan Sistem. Informasi), vol. 7, no. 1, pp. 29-41, 2020, doi: 10.35957/jatisi.v7i1.290.

[6] S. A. Salloum and K. Shaalan, "Investigating students' acceptance of E-learning system in Higher Educational Environments in the UAE: Applying the Extended Technology Acceptance Model (TAM)," Br. Univ. Dubai, no. September, pp. 1-102, 2018, [Online]. Available:

http://bspace.buid.ac.ae/handle/1234/1150\%0Ahttps://www.researchgate.net/profile/Said_Salloum/publicati on/327418762_Investigating_students\%27_acceptance_of_E-

learning_system_in_Higher_Educational_Environments_in_the_UAE_Applying_the_Extended_Technolog 
y_Ac.

[7] Rusman, Model-Model Pembelajaran. Rajagrafindo Persada, 2013.

[8] S. Jamal, “Analisis Kesiapan Pembelajaran E-Learning Saat Pandemi Covid-19 Di Smk Negeri 1 Tambelangan," J. Nalar Pendidik., vol. 8, no. 1, p. 16, 2020, doi: 10.26858/jnp.v8i1.13561.

[9] E. Fatmawati, "Technology Acceptance Model (TAM) untuk Menganalisis Sistem Informasi Perpustakaan," Iqra' J. Perpust. dan Inf., vol. 9, no. 1, pp. 1-13, 2015, [Online]. Available: http://jurnal.uinsu.ac.id/index.php/iqra/article/view/66.

[10] F. D. Davis, "Perceived usefulness, perceived ease of use, and user acceptance of information technology," MIS Q. Manag. Inf. Syst., vol. 13, no. 3, pp. 319-339, 1989, doi: 10.2307/249008.

[11] Z. Niqotaini, “Analisis Penerimaan Google Classroom Menggunakan Pendekatan Technology Acceptance Model (TAM) Dan End-User Computing Satisfaction (EUCS) (Studi Kasus: Universitas Informatika Dan Bisnis Indonesia)," Sistemasi, vol. 10, no. 3, p. 637, 2021, doi: 10.32520/stmsi.v10i3.1376.

[12] D. N. S. Wati and A. D. Indriyanti, "Pengukuran Penerimaan Teknologi dan Pengaruh Kualitas E-Learning terhadap Efektifitas Pembelajaran pada Perguruan Tinggi Menggunakan Metode TAM dan Webqual," $J$. Emerg. Inf. ..., vol. 02, no. 03, pp. 1-7, 2021, [Online]. Available: https://ejournal.unesa.ac.id/index.php/JEISBI/article/view/40993. 